\section{Problemas conjugais e outros fatores associados a transtornos psiquiátricos do pós-parto}

\section{Marital problems and other factors associated with postpartum psychiatric disorders}

\author{
Caros Editores, \\ O objetivo desta carta é a comunicação do resultado de estudo
} da associação entre fatores demográficos, psicossociais, pré e perinatais e doenças psiquiátricas pós-parto.

São alarmantes as prevalências de transtorno mental pós-parto encontradas nos estudos brasileiros ${ }^{1,2} \mathrm{e}$ internacionais. Isso inclui os índices encontrados por nosso grupo de pesquisa ${ }^{3,4}$. A identificação dos fatores de risco psicossocias pode levar à identificação precoce e ao enfrentamento dos agravos à saude da mulher e de seu filho resultantes dos transtornos mentais nesse período da vida.

Nosso grupo trabalha uma linha de pesquisa que estuda o desenvolvimento de famílias através de seu acompanhamento longitudinal. No decorrer do ano de 1999, foram identificadas todas as famílias $(n=230)$ de um bairro que tiveram filhos em hospital público por meio das notificações de nascimento da Prefeitura de Porto Alegre-RS. As famílias identificadas que aceitaram participar $(n=148)$ foram visitadas por dois terapeutas de família, sendo realizadas observações, entrevistas semiestruturadas e aplicadas escalas. Fatores demográficos, psicossociais e relacionais foram estudados. A saúde mental das mães e pais foi avaliada pelo Self Report Questionnaire (SRQ20). A Escala Avaliação Global do Funcionamento Relacional (GARF) do Manual Diagnóstico e Estatístico de Transtornos Mentais- $4^{a}$ edição-Texto revisado (DSM-IV-TR) foi usada para aferir a qualidade do relacionamento do casal e do relacionamento materno com sua família de origem, com a família paterna e com a rede social.

No estudo realizado aos quatro meses do bebê, $34,45 \%$ das 148 mulheres entrevistadas apresentaram suspeita de transtorno psiquiátrico. Sessenta e dois por cento das mulheres coabitavam com companheiro, sendo que estes também foram entrevistados. Dos 118 pais, 25,4\% apresentaram suspeita de transtorno mental. Nesta população, o fato de coabitar ou não com companheiro não esteve associado com transtorno mental. $\mathrm{Na}$ análise de regressão logística estudando a totalidade do grupo de mulheres, os fatores que se mostraram relacionados com possível transtorno mental foram a baixa renda familiar $(\mathrm{p}=0,017)$ e a presença de transtorno psiquiátrico materno no passado $(\mathrm{p}=0,043)$. Na regressão logística feita exclusivamente com as mulheres que viviam com companheiro, apenas a má qualidade da relação do casal esteve associada à presença de transtornos psiquiátricos quatro meses após o parto $(\mathrm{OR}=7,34, \mathrm{p}=0,001)$.

As altas prevalências de transtornos mentais das mães e pais são preocupantes, mas sua associação com problemas conjugais nos casais que coabitam identificam um evento familiar com possibilidades terapêuticas comprovadas ${ }^{5}$. Por outro lado, nas famílias uniparentais a associação com fatores socioeconômicos e história de transtorno prévio também indicam o caminho preventivo a seguir. Estes índices não parecem ser resultado de erro de aferição, porque os dados de prevalência são semelhantes aos de Coutinho et al. e aos de Cruz et al., 32,9\% de sintomas depressivos e $37,1 \%$ de transtorno mental pelo SRQ, respectivamente.

Este estudo reforça a necessidade de verificar a saúde mental da mãe no pré-natal e nas consultas de puericultura e introduz dados sobre a saúde mental do pai, especialmente sobre a importância de avaliar rotineiramente a relação conjugal nas consultas pré-natais e de puericultura. É relevante e ainda pouco enfatizada na literatura a importância da associação entre transtorno mental pós-parto e problemas conjugais.

Suzi Roseli Kerber Programa de Pós-Graduação, Universidade Federal do Rio Grande do Sul (UFRGS), Porto Alegre, RS, Brasil

Olga Garcia Falceto Departamento de Psiquiatria, Faculdade de Medicina, Universidade Federal do Rio Grande do Sul (UFRGS), Porto Alegre, RS, Brasil

Carmen Luiza C. Fernandes

Programa de Residência de Medicina de Família e Comunidade, Gerência da Saúde Comunitária, Grupo Hospitalar Conceição, Porto Alegre, RS, Brasi 
Financiamento e conflito de interesses

\begin{tabular}{|c|c|c|c|c|c|c|c|}
\hline $\begin{array}{c}\text { Membro do grupo } \\
\text { de autores }\end{array}$ & $\begin{array}{l}\text { Local de } \\
\text { trabalho }\end{array}$ & $\begin{array}{l}\text { Verba de } \\
\text { pesquisa }{ }^{1}\end{array}$ & $\begin{array}{c}\text { Outro apoio à } \\
\text { pesquisa ou educação } \\
\text { médica continuada }^{2}\end{array}$ & $\begin{array}{c}\text { Honorários } \\
\text { de } \\
\text { palestrantes }\end{array}$ & $\begin{array}{l}\text { Participação } \\
\text { acionária }\end{array}$ & $\begin{array}{c}\text { Consultorl } \\
\text { conselho } \\
\text { consultivo }\end{array}$ & Outro \\
\hline Suzi Roseli Kerber & UFRGS & - & - & - & - & - & - \\
\hline Olga Garcia Falceto & UFRGS & - & - & - & - & - & - \\
\hline $\begin{array}{l}\text { Carmen Luiza C. } \\
\text { Fernandes }\end{array}$ & $\begin{array}{c}\text { Grupo } \\
\text { Hospitalar } \\
\text { Conceição }\end{array}$ & - & - & - & - & - & - \\
\hline
\end{tabular}

* Modesto

** Significativa

*** Significativa. Montantes fornecidos à instituição do autor ou a colega onde o autor tem participação, não diretamente ao autor.

Nota: UFRGS = Universidade Federal do Rio Grande do Sul

Mais informações consultar as Instruções aos Autores.

Referências

1. Coutinho DS, Baptista MN, Morais PR. Depressão pós-parto: prevalência e correlação com suporte social. Infanto Rev Neuropsiquiátr Infânc Adolesc. 2002;10(2):63-71.

2. Cruz EBS, Simōes GL, Faisal-Cury A. Post-partum depression screening among women attended by the Family Health Program. Rev Bras Ginecol Obstet. 2005;27(4):181-8.

3. Falceto OG, GiuglianI E, Fernandes CL. Couples' Relationships and breastfeeding: is there an association? J Hum Lact. 2004;20(1):46-55.
4. Hollist CS, Miller RB, Falceto OG, Fernandes CL. Marital satisfaction and depression: a replication of the Marital Discord Model in a Latino Sample. Fam Process. 2007;46(4)485-98.

5. Pinsof WM, Wynne LC. The effectiveness and efficacy of marital and family therapy: introduction to the special issue. J Mar Fam Ther. $1995 ; 21(4): 341-2$

\section{Bipolar disorder and multiple sclerosis: comorbidity and risk factors}

\section{Transtorno bipolar e esclerose múltipla: comorbidade e fatores de risco}

Dear Editor,

Multiple sclerosis (MS) is a demyelinating central nervous system (CNS) disease that affects mainly young adults. The disease course is unpredictable, and clinical manifestations include motor deficits, sensory changes, bladder and bowel dysfunction, uni- optical neuritis, diplopia, and cerebellar signs. Rarely, MS may initially present itself as a manic syndrome, similar to that observed in bipolar disorder (BD). ${ }^{1}$ We report a patient diagnosed with BD who was later diagnosed with MS. The possibility of mania as a symptom or comorbidity of MS was examined in this case report to assess possible risk factors.

\section{Case report}

The patient, JPS, is a 50-year-old divorced female. In 1999, she developed euphoria, irritability, impulsivity, and grandiose delusions. For example, she started taking various classes to achieve grandiose goals, pursuing unrealistic business ideas, acquired several debts that she could not repay, requested dismissal from her employment because she believed she would become a millionaire, exhibited inappropriate seductive behavior, and placed an advertisement in a newspaper offering call girl services that resulted in the termination of her marriage. At that time, her relatives noticed that she was experiencing psychomotor agitation, aggressiveness, auditory hallucinations and delirious ideas; she was admitted to a psychiatric clinic for treatment, and her psychotic symptoms subsequently went into remission with the use of haloperidol plus promethazine. After six months, she presented with daily sadness, anhedonia, psychomotor retardation and fatigue; these symptoms were resolved with $20 \mathrm{mg} /$ day of fluoxetine. In 2000, she developed a subacute motor deficit on her left side and gait impairment, both of which partially improved spontaneously. At that time, her CT scan was normal. In 2001, she developed urinary incontinence and was referred for neurological assessment. A clinical examination revealed left hemiparesis, spasticity, and tendon reflexes that were brisk on the left side, and normal on the right side. Her cutaneous-plantar reflex was equivocal on the left side and resulted in toe flexion on the right side, and her gait was hemiparetic on the left side. The remainder of the neurological examination was normal. Magnetic resonance imaging (MRI) of her brain showed demyelinating periventricular lesions (Figure 1). An MRI scan of her cervical cord also showed demyelinating lesions. Autoantibody (anti-Ro, anti-LA, anti-Sm, ANA, anti-DNA and anticardiolipin) and serology (syphilis, hepatitis B and C, HIV and HTLV) tests were negative. Analysis of the cerebrospinal fluid (CSF) detected the presence of oligoclonal bands. Visual evoked potentials showed increased latencies and reduced amplitudes. Based on these findings, the patient was diagnosed with MS, and treatment was initiated with interferon beta-1A. During the nine years of 